\title{
Szempontok a magyar területfejlesztési intézmények vizsgálatához
}

\author{
Assessing Hungarian territorial development \\ institutions
}

\author{
SIMÓ BALÁZS
}

SIMÓ Balázs: doktorjelölt, Pécsi Tudományegyetem, Közgazdaságtudományi Kar, Regionális Politika és Gazdaságtan Doktori Iskola; 7622 Pécs, Rákóczi út 80.; simo.balazs.mate@gmail.com; https://orcid.org/0000-0002-5492-5506

KULCSSZAVAK: regionalizmus; közigazgatás; kapacitásfejlesztés

ABSZTRAKT: Noha Magyarország az 1990-es években a posztszocialista országok közül élen járt a területfejlesztési intézményrendszer kiépítésében, a 2012-es jogszabályi változások nyomán a 2014-2020-as uniós költségvetési ciklusban a regionális fejlesztési ügynökségek nincsenek már jelen. Megszűnésük teret adott hasonló rendeltetésű központi kormányzati és területi önkormányzati szervezetek kibontakozásának. A szervezetek intézményi betagozódásával, kapacitásfejlesztésével és a rájuk delegált feladatokkal kapcsolatosan kérdés, hogy azok összhangban vannak-e a versenyképességet alapvetően befolyásoló globális folyamatokkal.

Jelen tanulmány arra világít rá, hogy a fejlett országok regionális fejlesztési ügynökségei miként alkalmazkodnak ezekhez a globális folyamatokhoz. A cikk amellett érvel, hogy a regionális fejlesztési ügynökségek funkcióját betölteni kívánó hazai szervezeteknek igazodniuk kell a tudásalapú gazdaság által támasztott követelményekhez. Így már nem elegendő, ha a szervezetek összetett eszközrendszer által, relatív függetlenségben látják el feladataikat. Szükséges, hogy tevékenységeik a szektorok átjárhatósága mellett képesek legyenek biztosítani az információ és a tudás összegyűjtését, feldolgozását, valamint a helyi partnerek számára történő megosztását. E cél elérése érdekében ki kell alakítani azon értékelési szempontrendszert, mely támogatja e szervezeti képességek objektív megítélését és nemzetközi összehasonlíthatóságát.

Balázs SIMÓ: PhD candidate, Doctoral School in Regional Policy and Economics, Faculty of Business and Economics, University of Pécs; Rákóczi út 80., H-7622 Pécs, Hungary; simo.balazs.mate@gmail.com; https://orcid.org/0000-0002-5492-5506

KEYWORDS: regionalism; public administration; capacity development

ABSTRACT: In the post-2020 period, the European Commission will continue to focus on the challenges of the knowledge-based economy while maintaining a strong territorial approach and increasing synergy and coordination of the relevant sectoral financial resources and policies. The

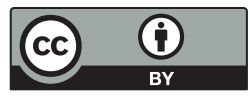


question is whether Member States are ready to face challenges such as globalisation, the digital revolution, economic governance, demographic change and social cohesion.

Although Hungary has played a pioneering role in Central and Eastern Europe in creating the legal and institutional framework for territorial development, the current EU budget period 2014-2020 is the first in which the Hungarian regional development agencies (RDAs) are no longer operational due to a 2012 legislative act. The closure of these institutions left room for other organisations with a similar mandate, operating at both central and territorial level.

There are doubts as to whether the capacity building of these institutions, given their reassigned tasks, is able to keep pace with the ever-changing global processes with a direct impact on competitiveness. Although regional development agencies have been an essential instrument of territorial development policy over the last seven decades, the paradigm shift in European regional policy calls into question the usefulness of its traditional instruments.

The main objective of this study is to examine the constantly changing environment and its impact on the RDAs of developed countries in order to define their development and adaptation potential through desk research and interviews. This study seeks to highlight the historical adaptation of territorial development institutions and points out that in a knowledgebased economy, governments are only able to increase competitiveness if they have institutions that enable adaptability and knowledge transfer.

With such research, the author wishes to underline the need to adapt the expectations and evaluation criteria for Hungarian territorial development institutions to the requirements of the knowledge-based economy. The fulfilment of purely operational development tasks by a quasiautonomous organisation with a multitude of means is no longer adequate. In addition to increasing synergies between the sectors, the ability to collect, process and exchange information with local authorities seems to be indispensable also for the current territorial development institutions. In order to develop these capabilities, a clearly defined criteria grid is needed, which can not only contribute to the objective evaluation of the current Hungarian institutions, but also provide the basis for an international comparison.

\section{Bevezetés}

Magyarország az 1990-es években Kelet-Közép-Európában élen járt a területfejlesztési intézményrendszer kiépítésében és müködtetésében. Az évtized közepétől a területfejlesztésre fordított források mind nagyobb hányadát tették ki az uniós előcsatlakozási alapok (az ISPA, a SAPARD és a PHARE), az EU-hoz való csatlakozást követően pedig a kohéziós politika megvalósítását támogató eszközök (pl. strukturális alapok és a kohéziós alap) (Nemzeti Fejlesztési és Gazdasági Minisztérium 2009). A források elosztásában részt vevő szervezetek közül zászlóshajóvá nőtték ki magukat a csatlakozás idejére már országos lefedettséggel bíró regionális fejlesztési ügynökségek (RFÜ-k), melyek közreműködő szervezeti feladatokat láttak el a területfejlesztési operatív programokban (Józsa 2016). A 2004-2006-os, Magyarország számára csonka programozási időszak Regionális fejlesztés operatív programja esetében az ügynökségek a VÁTI Magyar Regionális Fejlesztési és Urbanisztikai Kht.-val (VÁTI) közösen látták el a közreműködő szervezeti tevékenységet. A 2007-2013-as uniós költségvetési periódusban az RFÜ-k önállóan töltötték be ezt a funkciót a hét tervezési-statisztikai régió különálló regionális operatív programjai esetében. A 2014-2020-as 
időszak kiegyensúlyozott területi fejlődését elősegíteni hivatott Terület- és településfejlesztési operatív programjának (TOP) tervezésében és végrehajtásában azonban a kormányzat nem delegált az ügynökségek számára hasonló feladatkört. 2011-ben döntött úgy a kabinet, hogy megérett az idő a területfejlesztésről és a területrendezésről szóló 1996. évi XXI. törvény (Tftv.) átfogó, főleg a területfejlesztési intézményrendszert érintő módosítására (2011. évi CXCVIII. törvény). A 2012. január 1-jén hatályba lépett módosítások egyik fontos pillére a fejlesztéspolitikai intézményrendszer megújítása volt. Megszüntek a regionális fejlesztési tanácsok (RFT-k), a területfejlesztés középszintjévé a megyei önkormányzat vált; a közszolgáltatási szerepkör elvesztését a területfejlesztési funkció elvi lehetőségével kompenzálták. Az addig RFT-tulajdonban lévő regionális fejlesztési ügynökségek finanszírozását a regionális operatív programok technikai segítségnyújtási keretéből biztosító szerződések 2015. december 31-én lejártak, meghosszabbításukra nem került sor. Ez kihívás elé állította az egyébként is forráshiányos megyei önkormányzatokat az RFÜ-k finanszírozása szempontjából. A megyei közgyűlések 2016 év elejétől napirenden tartották az ügynökségek végelszámolással történő megszüntetését és megannyi esetben döntöttek is arról. Az RFÜ-k megszüntetése alkalmat adott a kormányzat és a megyei önkormányzatok számára, hogy újragondolják, kiépítsék és megerősítsék területfejlesztési kapacitásaikat. $\mathrm{Az}$ azonban kérdés maradt, hogy egyrészt az elmúlt évek irányváltása összhangban van-e a nemzetközi trendekkel, másrészt az irányváltással a végrehajtás lépést tud-e tartani. Ennek vizsgálatához megfelelő szempontrendszerre van szükség.

A hazai szakirodalom még nem vizsgálta az érintett magyar szervezeteket összetett szempontrendszer szerint. Nemzetközi összehasonlításra is csak az európai uniós programozási ciklusok területfejlesztési programjainak az Európai Bizottság által készített éves jelentései szolgálnak. Azonban e jelentések kizárólag az intézmények forráselosztásban betöltött, közreműködő szervezeti tevékenységére összpontosítanak.

Ebben a tanulmányban bemutatom azokat a nemzetközi folyamatokat, amelyek igényként fogalmazták meg az ügynökségi típusú szervezetek létrejöttét, valamint azon kutatói törekvéseket, melyek igyekeztek a területfejlesztéssel foglalkozó ügynökségeket minőségileg kategorizálni. A tanulmány további fejezeteiben áttekintem, hogy a tudásalapú gazdaság kihívásai hatására a szervezetek milyen fejlődésen mennek keresztül, és ez mely területeken igényli az értékelési rendszer felülvizsgálását. Az összegzésben felhívom a figyelmet arra, hogy a 2012-ben megindult magyar intézményrendszeri átalakulás nyomán a jelenlegi területfejlesztési intézményrendszer értékelésére is szükség volna. 


\section{A vizsgálati szempontrendszer kialakításának időszerüsége}

Az RFÜ-k megszüntetésével hátrahagyott ürt a kormányzat közvetlenül is igyekezett kezelni. A 68/2011. (IV.28.) Korm. rendelet alapján a Széchenyi Programiroda Nkft. miniszteri szintű felügyelet mellett, de megyei jelenléttel, pályázóközpontúan támogatja az uniós társfinanszírozású pályázatok benyújtását és megvalósítását. Továbbá nemcsak részt kellett vennie a 2014-2020-as programozási időszak tervezési feladataiban, hanem az Új Széchenyi-terv (ÚSZT) célkitűzéseinek helyi szintű megvalósulását is támogatnia kellett. A TOP közreműködő szervezeti feladatkörének ellátására a kabinet 2013-ban a szintén központi kormányzati irányítás alatt álló Magyar Államkincstárat jelölte ki, amely a feladatot megyei igazgatóságai által, dekoncentráltan látja el. A kormányzat a névválasztással (Széchenyi Programiroda, regionális fejlesztési ügynökség, központ), valamint a társasági formával (Nkft., Nonprofit Zrt.) igyekezett rámutatni arra, hogy az önkormányzati hierarchián kívüli, eredményorientált gazdasági társaságokat kíván létrehozni.

A névválasztás és a társasági forma meghatározása alapítói vagy tulajdonosi döntés. Felmerül a kérdés, hogy a név- és a társaságiforma-választást követően sikerül-e a szervezeteket olyan minőségű és mennyiségű tartalommal megtölteni, amely eleget tesz az alapítói szándékoknak. Ennél is sarkalatosabb, hogy az alapítói szándékok és a jogalkotói elvárások összhangban vannak-e egymással és tartják-e a lépést a versenyképességet alapvetően befolyásoló globális folyamatokkal. A kérdés megválaszolása olyan vizsgálati szempontrendszert feltételez, mely illeszkedik a nemzetközi értékelési szempontrendszerekhez és tekintettel van a releváns és aktuális paradigmákra is - hiszen utóbbiak formálják a területi fejlesztéspolitikai szervezetekkel szembeni elvárásokat és e szervezetek jellemzőit. A megfelelő szempontrendszer nemcsak a szervezetek objektív, szakmai szempontok szerinti nemzetközi összehasonlítását és minősítését segíti, de meghatározhatja azt a fejlődési irányt is, mely a területi és az országos versenyképesség megőrzéséhez szükséges.

A kutatás időszerűségére és az értékelési szempontrendszer szükségességére a 2018 májusa és októbere között az RFÜ-k témakörében készített félig strukturált interjúim is rámutattak. Egyrészt a területfejlesztésben évtizedes tapasztalattal bíró szakemberek meglátása szerint az átalakított területfejlesztési intézményrendszerrel kapcsolatos „türelmi idő” véget ért, így a gyakorlati tapasztalat birtokában időszerűvé vált az intézményrendszer értékelése. Másrészt az interjúalanyok a közremúködő szervezeti feladatokon túl - a nyugati ügynökségek széles portfóliójával szemben - mindössze a nemzetközi (uniós) projektekben való részvételt és az állami megrendelésre végzett tervezési feladatok ellátását jelölték meg. Így a szervezetek nemzetközi összehasonlíthatósága érdekében az értékelési szempontok kialakításakor hangsúlyt fektettem arra, hogy lehetőség legyen a projektpartneri és tervezési feladatokon kívüli lehetséges ügynökségi tevékenységek vizsgálatára. 
A továbblépéshez érdemes megvizsgálni, hogy milyen RFÜ-s minősítési rendszerek léteznek, hiszen ezek megfelelő alapjai lehetnek újabb szempontrendszer kidolgozásának, a jelen kor folyamataihoz és paradigmáihoz való igazítás után.

\section{A regionális fejlesztési ügynökségek 20. századi tipológiája}

A jóléti állam 70-es és 80-as évekre kimerülő tartalékai miatt a munkanélküliség csökkentésében a termelékenység, a profitráta, a likviditás, illetve az export növelése vált elsődlegessé. A fejlett államok többsége területi (legtöbbször regionális) megközelítéssel fogott hozzá a területi közigazgatás és közszolgáltatás, valamint a területi fejlesztéspolitikai intézményrendszer megszervezéséhez. Az 1. táblázat szemlélteti a centralizált központi kormányzati, valamint az alulról építkező, decentralizált regionális politikák közötti alapvető különbségeket.

A fentiek nyomán elvárássá vált, hogy a közintézmények ,aktív interface”-szé és rendszerintegrátorrá váljanak, szakítva a korábbi kizárólagos szabályozói szemlélettel és szerepkörrel. Így Nyugat-Európában megalakultak a kvázi autonóm regionális fejlesztési ügynökségek. A regionális beágyazottságú fejlesztési szervezetek tipizálása meglehetősen összetett feladat: nemcsak a régió értelmezése sokrétű, de a fejlesztési intézmények sajátosságai is különbözőek. A központi szint alatti és a helyi önkormányzati szint feletti területi menedzs-

1. táblázat: A centralizált, felülről építkező és a decentralizált, alulról építkező regionális fejlesztéspolitikai megközelítés

The centralized, top-down and the decentralized, bottom-up regional development policy approach

\begin{tabular}{lll}
\hline \multicolumn{1}{c}{ Jellemzö } & \multicolumn{1}{c}{ Centralizált } & \multicolumn{1}{c}{ Decentralizált } \\
\hline Szervezet & Nemzeti & Regionális \\
& Központi kormányzati egység & Kvázi független szervezet \\
& Bürokratikus & Piaci felépítés \\
& Általános képesítés és múlt & Specifikus szaktudás \\
\hline Működési szabadság & Korlátozott & Kartávolságnyi (arm's length) \\
\hline Gazdasági célkitűzés & Interregionális egyenlőség & Interregionális versenyképesség \\
& Nemzetgazdasági növekedés & Regionális gazdasági növekedés \\
& A növekedés újraelosztása & Endogén/importált növekedés \\
\hline Müködési mód & Nem szelektív & Szelektív \\
& Automatikus/diszkrecionális & Diszkrecionális \\
& Reaktív & Proaktív \\
\hline Szakpolitikai eszközök & Bürokratikus szabályozás & Pénzügyi ösztönzők \\
& Pénzügyi ösztönzők & Tanácsadói szolgáltatások \\
& Tanácsadói szolgáltatások & Közintézkedés \\
& Közintézkedés & \\
\hline
\end{tabular}

Forrás: Danson, Halkier, Dambora (1998). 
ment Európában felöleli a német önkormányzatokat, a spanyol autonóm tartományokat vagy az Egyesült Királyság nemzetrészeit. A témával foglalkozó kutatók többsége elfogadja a regionális fejlesztési ügynökség Halkier és Danson-féle definícióját (1997), miszerint az RFÜ olyan 1. regionálisan beágyazott közfinanszírozású szervezet, mely 2. független szereplőként, 3. a központi és a helyi kormányzati struktúrán kívül működve támogatja a gazdasági fejlődést. E három kritériumot a későbbiekben újabb jellemzőkkel egészítették ki: az ügynökségek 4. alapvetően „szoft” szakpolitikai eszközökkel támogatják a régiós (endogén) vállalkozásokat; valamint 5. integrált megközelítéssel, széles eszköztárral végzik feladataikat (Danson, Halkier, Damborg 1998).

Előbbi sajátosságok nyomán a hierarchikus államigazgatási intézményi struktúrákkal szemben az RFÜ-k mint alulról felfele szerveződő alternatívák kellő távolságot tartanak a helyi kezdeményezések néha elaprózott rendszerétől. Ennek ellenére megfelelő rugalmassággal és fogékonysággal tudták a sajátos kihívásokat kezelni. A kormányzati apparátustól való távolság megadta a lehetőséget az ügynökségeknek, hogy olyan üzleti szellemben tegyenek a közpolitikai célok eléréséért, melyek mentesek voltak a túlzó állami beavatkozások jellemzőitől. Halkier és Danson (1997) négy további előnyt tulajdonított a regionális szervezeteknek:

- Mindenekelőtt helyi betagozódásuk miatt sokkal alkalmasabbak arra, hogy a régiónként eltérő kihívásokra egyéni stratégiákkal próbáljanak választ adni.

- Az új, alulról építkező regionális politika olyan szakemberállományt követelt meg, amely képes az üzleti szemléletre és a vállalkozói szférával való kapcsolattartásra.

- A félig autonóm helyzet távolságot biztosított a napi politikától, így stratégiaibb gondolkodás lehetséges. A „kartávolságra levo müködési függetlenség" (arm's-length degree of operational freedom) felállásában a politikai és anyagi támogatók rendelkeztek az alapvető erőforrások elosztásáról, a szakpolitikai és stratégiai célkitüzésekről. Az ügynökség a célok eléréséhez szükséges operatív feladatokról és azok végrehajtásáról döntött.

- Az állami szintű szakpolitikával összehasonlítva egy regionális szervezet erőteljesebben mutathatta a helyi politikai elit regionális fejlesztés iránti elkötelezettségét.

Halkier és Danson 1997-ben hét nyugat-európai ország regionális fejlesztési ügynökségeit vizsgálva kereste az intézmények kulcsjellemzőit. Alapvetően a szervezeti sajátosságokat, a szakpolitikai programokat, valamint azok végrehajtását vizsgálták. A felállított kritériumrendszer alapján elemezhető az operatív tevékenységet jóváhagyó és támogató politikai hatalom, valamint a szakpolitikai végrehajtást végző apparátus viszonya. Alapvető különbség, hogy az ügynökség a politikai legitimációval bíró regionális hatalom apparátusán kívül helyezkedik-e el, vagy abba betagozódik. Ugyanis egy regionális tanácsi struktúrába való közvetlen betagozódás esetén magasabb a közvetlen politikai ellen- 
őrzés esélye, ami a hosszú távú stratégiai döntésekre és a szervezet napi életére is hatással van. Ezzel szemben a kartávolság esetében megvan a lehetőség arra, hogy a tulajdonos hatalma és befolyása mindössze az általános irányok meghatározására terjedjen ki. Így a stratégiai kezdeményezés, valamint a legfontosabb végrehajtási-döntési jogkör a menedzsment kezében maradhat. Ekkor jó eséllyel kialakul az ügynökség önálló (közszervezeti) identitása, mely a fejlesztéspolitikában a szervezeti és a politikai autonómiát növeli. Emellett fennáll a lehetősége annak is, hogy az RFÜ munkájára a tulajdonoson kívül több közintézmény is hatással legyen, ami a függőségi rendszert diverzifikálja. Természetesen az egyes esetek széles spektrumon helyezkednek el, a 2. táblázat az alapvető csoportokat foglalja össze.

A vizsgálat tárgyát képezte a tulajdonosok száma és kiléte is, különböző preferenciáik miatt. Olyan országokban, ahol az RFÜ-knek a központi kormányzat az egyedüli tulajdonosa (pl. a hivatkozott kutatás idején az Egyesült Királyság), a központi hatalom jellemzően nem kívánja, hogy a szervezetnek más támogatói is legyenek, különösen ne a regionális és helyi körökből. Ezzel a központi kormányzat szigorú ellenőrzést biztosít önmaga számára a szervezetek felett: fenntartja a jogot az igazgatóság tagjainak kinevezésére és visszahívására, a költségvetés biztosítására és módosítására, a politikai támogatottság garantálására vagy megvonására. A skála másik végén található a kartávolságra levő plurális tulajdonosi jelleg, amikor az RFÜ több, a regionális kormányzati hierarchia azonos szintjén álló szereplő támogatását élvezi.

A tulajdonosi szerkezet pluralitása döntően befolyásolja a szervezetek finanszírozását is. A szervezeti egységként betagozódott ügynökségek kizárólagosan a pénzügyi bizottságnak referáltak. Ezzel szemben a részben betago-

2. táblázat: Az RFÜ-k szervezeti függetlenségének típusai

Types of RDAs' organisational independence

\begin{tabular}{|c|c|c|c|}
\hline Kategória & Jogi státusz & Tulajdonos & A tulajdonoshoz való viszony \\
\hline $\begin{array}{l}\text { Ágazati } \\
\text { betagozódású }\end{array}$ & $\begin{array}{l}\text { A központi } \\
\text { kormányzat } \\
\text { része }\end{array}$ & $\begin{array}{l}\text { Központi } \\
\text { kormányzat }\end{array}$ & Közvetlen politikai ellenőrzés \\
\hline $\begin{array}{l}\text { Kváziágazati } \\
\text { betagozódású }\end{array}$ & $\begin{array}{l}\text { A központi } \\
\text { kormányzat } \\
\text { része }\end{array}$ & $\begin{array}{l}\text { Központi } \\
\text { kormányzat (és } \\
\text { egyéb szervezetek) }\end{array}$ & $\begin{array}{l}\text { Önálló tanácsadó testület által mediált } \\
\text { közvetlen politikai ellenőrzés }\end{array}$ \\
\hline $\begin{array}{l}\text { Kartávolságra } \\
\text { levő / egyedi }\end{array}$ & $\begin{array}{l}\text { Különálló } \\
\text { intézmény }\end{array}$ & $\begin{array}{l}\text { Központi } \\
\text { kormányzat }\end{array}$ & $\begin{array}{l}\text { Politikai felügyelet, az igazgatóság tagjait a } \\
\text { központi kormányzat delegálja }\end{array}$ \\
\hline $\begin{array}{l}\text { Kartávolságra } \\
\text { levő / domináns }\end{array}$ & $\begin{array}{l}\text { Különálló } \\
\text { intézmény }\end{array}$ & $\begin{array}{l}\text { Központi } \\
\text { kormányzat és } \\
\text { egyéb szervezetek }\end{array}$ & $\begin{array}{l}\text { Politikai felügyelet, az igazgatóság tagjait a } \\
\text { kormány jelöli ki, de a delegálásra } \\
\text { ráhatással bírnak különböző magán- és } \\
\text { közintézmények }\end{array}$ \\
\hline $\begin{array}{l}\text { Kartávolságra } \\
\text { levő / plurális }\end{array}$ & $\begin{array}{l}\text { Különálló } \\
\text { intézmény }\end{array}$ & $\begin{array}{l}\text { Kormány(ok) és } \\
\text { egyéb szervezetek }\end{array}$ & $\begin{array}{l}\text { Politikai felügyelet, a kormányok, a } \\
\text { magán- és közintézmények delegálják a } \\
\text { tagokat }\end{array}$ \\
\hline
\end{tabular}


zódott típusba tartozók a pénzügyi bizottság mellett többnyire beszámolással tartoztak olyan tanácsadó testületnek is, melyet a regionális tanács, az önkormányzatok, a helyi és regionális fejlesztési bizottságok, a kereskedelmi szervezetek és az üzleti szféra képviselői alkottak. A pénzügyi és a tanácsadói bizottság szerepe és befolyása országról országra és régióról régióra változott. Azonban a tanácsadói bizottság több esetben is hangsúlyosabbnak bizonyult, különösen, ha a regionális politikai vezető elnökölte azt, valamint ha a két fórum tagjai között nagyfokú átfedés jelentkezett.

Az ügynökségek finanszírozása kapcsán kulcskérdés a szakpolitikák végrehajtásának eszköztára és az ügynökségi funkciók kiterjedtsége. A szélesebb portfólió segítette a bevételi források diverzifikálását. A 3. táblázat a hagyományos és az új eszköztárat mutatja be.

Az előbbiek alapján meghatározható hogy egy szervezet mikor mondható modellértékủ RFÜ-nek. E sajátosságok nemcsak abban merülnek ki, hogy a szervezet a szüken vett bürokrácián kívül, kvázi függetlenségben lássa el feladatát, hanem legalább ennyire fontos, hogy az adott régió versenyképességét hosszú távú stratégia mentén élénkítse, és ehhez integrált eszközrendszert biztosítson a végrehajtás során. Összességében megállapítható, hogy a kilencvenes évek közepén a nyugat-európai RFÜ-k heterogén képet mutattak, ám lehetőség volt objektív sajátosságok mentén való kategorizálásukra.

3. táblázat: Az RFÜ-k szakpolitikai eszköztára Policy instruments of RDAs

\begin{tabular}{|c|c|c|}
\hline Szakpolitikai eszköz & Hagyományos & Új \\
\hline \multirow[t]{3}{*}{ Tanácsadás } & Finanszírozás, pályázati lehetőségek & Termelés \\
\hline & Nemzetköziesedés & Piaci környezet \\
\hline & & Általános üzletvitel \\
\hline \multirow[t]{2}{*}{ Finanszírozás } & (Részben saját) pályázati források & Hitel- és garanciatermékek \\
\hline & Egyéb & Kockázati tőke \\
\hline \multirow[t]{2}{*}{ Infrastrukturális fejlesztés } & Hagyományos ipartelepítés & Képzés \\
\hline & & Ipari parkok kialakítása \\
\hline
\end{tabular}

Forrás: Halkier, Danson (1997).

\section{Folyamatos ügynökségi fejlődés}

Az ezredforduló tájékán a fejlett országok ügynökségei új eszközrendszerek bevetésére kényszerültek. Már nem volt elegendő a tervezési feladatokban, a hálózatosodás elősegítésében, valamint a működő tőke bevonásában való aktív részvétel. Különösen a kevésbé fejlett régiókban megjelenő beruházásoknál szükségessé vált az utógondozás, mert korántsem volt biztos, hogy a kezdeti beruházást újrabefektetési döntések követik. E kockázat különösen magas volt 
az innovatív cégek esetében. Számukra az egyszeri vagy többszöri állami és/vagy regionális támogatásnál fontosabb volt a helyben található munkaerő képzettsége, a beszállítók megtalálása, valamint a magán- és a közszféra hálózatosodási képessége. Az intézmények tevékenysége eltolódott egyfajta brókeri tevékenység irányába (Morgan 1998). E törekvés első lépcsőjeként a helyi beszállítói képességek fejlesztésére fókuszáltak, ami többet jelentett a korábban ismert „vegyél helyit” szlogenek újbóli megismétlésénél:

- Több helyen beszállítói szövetségeket hoztak létre az ügynökségek.

- Jellemző és újszerű szolgáltatássá vált az új technológiák bevezetésének és elterjedésének a serkentése. Az ügynökségek vállalták az ígéretes vállalkozások technológiai auditjának az elvégzését, ami rámutatott a gyengeségekre és erősségekre.

- Aktívan részt vettek felsőoktatási intézményekhez kapcsolódó szakértői központok (centres of expertise) kialakításában (Goddard, Chatteron 1999).

- Hasonló célt szolgált a technológiai vívmányok integrálásában a technológiai klubok létrehozása és működtetése, melyek sikerrel serkentették az innovatív együttműködéseket.

- Sikeres, adaptációt segítő tevékenység volt a képzési konzorciumok megjelenése, melyek célcsoportja a kis- és középvállalatok munkavállalói voltak. A piaci elvárásoknak megfelelően alakult a képzési paletta, a regionális támogatásnak megfelelően a kis- és középvállalatok olcsóbban juthattak személyre szabott képzéshez.

A felsorolásból kitűnik, hogy bár a kevésbé fejlett régiók hosszú távú célja továbbra is a munkahelyteremtés, a munkanélküliség csökkentése volt, ezt egyre inkább a gazdaság versenyképességének növelésével és nem a kevéssé hatékony rendszerek támogatásával kívánták elérni. Ezáltal a fókusz a beruházások és munkaadók támogatásáról átkerült a marketingre, a kutatás-fejlesztésre, a menedzsmentkészségek és a munkaerő képzését biztosító keretfeltételek megteremtésére (Miles, Tully 2007). A nyugat-európai regionális fejlesztési ügynökségek portfóliója tehát folyamatosan bővült. Felvállaltak közlekedésfejlesztéssel, a turizmus promotálásával, nemzetközi kereskedelemmel kapcsolatos feladatokat is. Több országban formálisan hozzájárulhattak a központi költségvetés éves tervezéséhez.

\section{A tudásalapú gazdaság által átalakított regionális fejlesztési ügynökségek}

A 80-as évektől az európai regionális politika folyamatosan változott, melynek egyik legfontosabb aspektusa az iparalapú gazdaságról a tudásalapú gazdaságra való átállás (Bachtler, Yuill 2007). Az RFÜ-megközelítés létrejöttekor az ügynökséget még a 20. század két uralkodó intézménye, az állam és a piac között 
helyezték el. Ennek nyomán az RFÜ-k legfőbb rendeltetése az volt, hogy a rövid távon gondolkozó, magántulajdonban lévő gazdasági szereplők számára új lehetőségeket tárjanak fel, csökkentve az egyenlőtlen területi fejlődés negatív hatásait. A 21. század globalizált világának újabb kihívásai megkérdőjelezték az RFÜ-k koncepcióját. Ebben az új környezetben a tudásalapú gazdaság az uralkodó, ami az európai regionális politikát is átalakította (Cooke, De Laurentis 2010) (4. táblázat).

Előbbiekből kifolyólag a nemzetközi kapcsolódások megléte és fenntartása, valamint a tudáshoz való hozzáférés lépett elő a legfontosabb értékké és eszközzé. Alapvetően megváltozott a tudás szervezeten, vállalaton belüli létrejöttének, illetve régión belüli és kívüli áramlásának a módja, ez pedig felülírta a belső regionális erőforrások kiaknázására épülő korábbi elméleteket és gyakorlatot (Crevoisier, Jeannerat 2009). A folyamatok hatására az RFÜ mint egyedülálló, multifunkcionális regionális szakpolitikai tervező és végrehajtó intézmény nyomás alá került (Jones 2001). Hagyományos mozgásterük szűkülésében az olyan stratégiai megközelítések is szerepet játszanak, mint pl. az Európa 2020 stratégia. A stratégia által szorgalmazott politikai elszámoltathatóság, környezeti fenntarthatóság és társadalmi befogadás megkérdőjelezik az RFÜ-jellegü szervezeteknél a sajátos területi stratégiai kihívások és célok megvalósításának kizárólagosságát.

Ahogyan a gazdasági struktúrák és termelési folyamatok változnak, úgy válik egyre kívánatosabbá a nemzetközi aspektus erősítése, az új, tudásalapú gazdaság erőteljesebb támogatása. A Crevoisier és Jeannerat-féle (2009) „területi tudásdinamikák" kifejezés a külső kapcsolati háló kiépítésének a fontosságára mutat rá, ami elengedhetetlen a tudás megszerzése szempontjából. A szerzők hangsúlyozzák, hogy a közeljövőben azok a területek lesznek versenyképesebbek, amelyek kombinálni és fejleszteni képesek a kívülről megszerzett és elsajátított tudást. A felhalmozott tudás biztos alapokat adhat egy régió gazdasága számára. A kihívás abban rejlik, hogy milyen módszerek és intézményrendszer fogja egy terület számára biztosítani a megfelelő mennyiségü és minőségű információ és tudás „összehalászását” és feldolgozását.

A tudástranszferen alapuló regionális külső kapcsolódási pontok aktív kiépítésében a területfejlesztési szervezeteknek kulcsszerepe van. Ehhez fel kell

4. táblázat: Az európai regionális politika változó paradigmája The changing paradigm of the European regional policy

\begin{tabular}{lll}
\hline \multicolumn{1}{c}{ Jellemzö } & \multicolumn{1}{c}{ Ipari-gazdasági paradigma } & \multicolumn{1}{c}{ A tudásalapú gazdaság paradigmája } \\
\hline $\begin{array}{l}\text { Területi } \\
\text { kormányzás }\end{array}$ & $\begin{array}{l}\text { A támogatásra kijelölt } \\
\text { terület }\end{array}$ & Többszintü, alulról felfele építkezö \\
\hline Stratégia & $\begin{array}{l}\text { Magáncégekbe való } \\
\text { befektetés általi növekedés }\end{array}$ & $\begin{array}{l}\text { A megnövekedett tudásnak és hálózatosodásnak } \\
\text { köszönhetően végzett új gazdasági tevékenységek }\end{array}$ \\
\hline Eszközök & Pénzügyi & Információ, szervezetek \\
\hline
\end{tabular}

Forrás: Halkier (2012). 
nőnie a szervezetek legújabb generációjának, mivel a tudásdinamikák biztosítása széles körű tevékenységeket ölelhet fel a képzett munkaerő felvételétől az oktatáson, képzésen, tanácsadáson, kiszervezésen át a gyártók és fogyasztók közötti interakciók megteremtéséig (Crevoisier, Jeannerat 2009). A tudásdinamikák nem tisztelik az adminisztratív határokat. Sőt, kiemelkedően fontos az adminisztratív határok átlépése és a régiók közötti kapcsolódások megteremtése. Ezzel együtt a földrajzi közelség és a klaszterek miatt a régiók továbbra is fontos, önálló szereplői a tudás áramlásának (Visser, Atzema 2008). Az 5. táblázat hasonlítja össze az új területi tudásdinamikák paradigmáját a hagyományos paradigmával.

Könnyen megeshet, hogy a jövő területi beágyazottsággal bíró intézményeire már nem az RFÜ elnevezés lesz a megfelelő. Azonban megjósolható, hogy a nyugat-európai területfejlesztési szervezetek legfőbb tevékenysége a szervezeti és az információs (erő)források egyéb intézmények számára történő feltételes vagy feltétel nélküli rendelkezésre bocsátása lesz, míg a direkt pénzügyi transzferek szétosztásának jelentősége csökkenni fog. A változások viszont továbbra is feltételezik a rendszerszintü önszervező és összehangoló képességet, amelyekben az RFÜ-khöz hasonló önállóbb és területileg beágyazott szervezetek összetett problémamegoldó képességük révén komoly hozzáadott értékkel bírhatnak. A tudásdinamikák és az innováció - a kombinatív képesség nélkülözhetetlenségéből fakadóan - olyan szervezeteket, szakembereket és kompetenciákat követelnek, melyek képesek biztosítani a szektorok közötti átjárhatóságot. Így bár a szervezetek eszköztárának folyamatosan meg kell újulnia, de a területi jelenlét és beágyazódás értéke nem veszik el, illetve széles körü tevékenységük és relatív függetlenségük elengedhetetlen feltételei lesznek a sikeres alkalmazkodásnak.

5. táblázat: A területi tudásdinamikákra való átállás paradigmája Transition to the territorial knowledge dynamics paradigm

\begin{tabular}{lll}
\hline \multicolumn{1}{c}{ Jellemző } & \multicolumn{1}{c}{ Hagyományos paradigma } & \multicolumn{1}{c}{ Új paradigma: területi tudásdinamikák } \\
\hline $\begin{array}{l}\text { A változás } \\
\text { egysége }\end{array}$ & Innováció & Tudásdinamika \\
\hline $\begin{array}{l}\text { Az új tudás } \\
\text { mobilizálása }\end{array}$ & Pontszerü (technológiai pályagörbe) & Folyamatos \\
\hline $\begin{array}{l}\text { A tudás } \\
\text { artikulálása }\end{array}$ & Felhalmozás, gyüjtés & Kombinálás \\
\hline $\begin{array}{l}\text { Területi } \\
\text { lefedettség }\end{array}$ & $\begin{array}{l}\text { A tevékenységek és a munkaerö területi } \\
\text { megosztottsága }\end{array}$ & Többközpontú tudáshálózatok \\
\hline $\begin{array}{l}\text { Regionális } \\
\text { kormányzás }\end{array}$ & $\begin{array}{l}\text { Regionális koherencia a tudás } \\
\text { létrehozása és felhasználása esetében } \\
\text { (klaszter) }\end{array}$ & $\begin{array}{l}\text { A többközpontú dinamikában és a } \\
\text { tudásmobilizálásban való részvétel } \\
\text { képessége a megfelelő kapacitásokkal }\end{array}$ \\
\hline
\end{tabular}

Forrás: Cooke, Porter (2012). 
Ennek nyomán a Halkier és Danson-féle szempontokból csak néhánynak a felülvizsgálata szükséges. Az Európai Unió kohéziós politikájában egyre nagyobb hangsúlyt kapnak a városok és városrégiók. Így érdemes megvizsgálni, hogy mely földrajzi, funkcionális vagy adminisztratív régió a legelöremutatóbb egy operatív szervezet müködési területeként. Mindemellett hangsúlyozni szükséges, hogy az 1. táblázatban bemutatott alulról felfele tervező megközelítés nem vesztette el aktualitását. Így elképzelheto, hogy a „regionális” vagy az „ügynökségi” elnevezés lassan „kikopik”, azonban a területi kötődés és beágyazottság a jövőben is elengedhetetlen lesz. A jogi státusz, a tulajdonos jogi személye és az ahhoz füződő viszony szempontjából továbbra is a minél nagyobb szabadság az optimális. A szervezetek eszközrendszere esetében azonban meg kell határozni azt az új palettát, mellyel sikeresen lehet a napi múködésben információkat összegyüjteni, azokat értelmezni, az adott terület sajátosságaira szabni, valamint a területi szereplők számára továbbadni.

\section{Összegzés}

Magyarországon nemcsak hogy az RFÜ-k státusza és funkciója kérdőjeleződött meg, hanem kis kivétellel (Pro Regio Nonprofit Közhasznú Kft.) meg is szüntették őket. Mindemellett a területfejlesztési kihívásoknak Magyarországon számos szervezet igyekszik eleget tenni: például megyei fejlesztési ügynökségek, kormányzati gazdasági társaság (a Széchenyi Programiroda), kormányzati dekoncentrált központi költségvetési szerv (a Magyar Államkincstár mint a TOP-ok közreműködő szervezete), valamint szaktárca (Pénzügyminisztérium - TOP Irányító Hatóság). Az elnevezés és a társasági forma rámutat arra a törekvésre, hogy e szervezetek eleget tudjanak tenni a 90-es évek közepén meghatározott alapvető kritériumrendszernek: a területi beágyazottságnak, a kormányzati és területi adminisztráción kívül való elhelyezkedésnek és ebből fakadóan a nagyobb fokú müködési függetlenségnek.

A tanulmány áttekintette a három kritérium mellett a területi beágyazottsággal múködő szervezetek azon további sajátosságait, melyek érdemben befolyásolják működésük minőségét és a szervezetek szerepét az adott terület versenyképességének elősegítésében. Ilyen többek között a jogi státusz, a tulajdonosi kör, az azokhoz való viszony, illetve az eszközrendszer és a humán erőforrás.

A folyamatosan változó környezet miatt a szervezetek állandó változási kényszer alatt állnak. Ennek fő dinamizálója napjainkban a tudásalapú gazdaság. A változások azon szervezeteknek kedveznek, melyek a hármas kritériumrendszernek eleget tudnak tenni, valamint biztosítják a „szoft” szakpolitikai eszközök széles tárházát, így közelíteni tudnak a 90-es évek derekán definiált RFÜ-modellhez. Azonban az eszközrendszer meg kell, hogy újuljon. A jövőbeli 
kutatások egyik iránya az eszközrendszerrel szemben támasztott elvárások kimunkálása, pontos megnevezése és a működési terület ideális lefedettségének felülvizsgálata. Emellett az átalakult hazai területfejlesztési intézményrendszer működéséről is felhalmozódott annyi gyakorlati tapasztalat, hogy a „türelmi idő" lejártát követően az újonnan felállt rendszer kutatás tárgyát képezhesse. E vizsgálatoknak meg kell határozniuk a területfejlesztési rendszer operatív szereplőivel kapcsolatos elvárásokat. Szükséges, hogy e kutatások ne csak a hazai szakpolitika jogszabályai által meghatározott jogokat és felelősségeket elemezzék, hanem a tudásalapú gazdaság által támasztott, nemzetközi szakirodalomban taglalt kihívásokat is. Vagyis azon követelményeket, melyek szervezeti és rendszerszinten lehetővé teszik az információ és a tudás összegyűjtését, feldolgozását és helyi partnerekkel való megosztását. A vizsgálatok így nemcsak a szervezetek objektív nemzetközi összehasonlítását fogják segíteni, hanem formálni tudják a helyi politikával, a szakpolitikával és a jogszabályalkotó intézményrendszerrel szemben támasztott elvárásokat, az azok végrehajtását biztosító felhatalmazást és eszközrendszert.

\section{Irodalom}

Bachtler, J., Yuill, D (2007): Regional policy in Western Europe: taking stock of the shift in paradigm. RUFIS Beiträge zur Ballungsraumforschung.

Cooke, P., De Laurentis, C. D. (2010): Trends and drivers of knowledge economy. In: Cooke, P., De Laurentis, C. D., Collinge, C., Macneill, S. (eds.): Platforms of innovation: Dynamics of new industrial knowledge flows. Edward Elgar, London, 1-26. http://doi.org/c7kx

Cooke, P., Porter, J. (2012): Smart RDAs in Europe: Advanced practices. In: Bellini, N., Danson, M., Halkier, H. (eds.): Regional development agencies: the next generation? Routledge, New York, 206-225.

Crevoisier, O., Jeannerat, H. (2009): Territorial knowledge dynamics: from the proximity paradigm to multi-location milieus. European Planning Studies, 8., 1223-1241. http://doi.org/dt8qx8

Danson, M., Halkier, H., Damborg, C. (1998): Regional development agencies in Europe. An introduction and framework for analysis. In: Halkier, H., Danson, M., Damborg. C. (eds.): Regional development agencies in Europe. Routledge, London, 13-25. http://doi.org/c7kz

Goddard, J. B., Chatterton, P (1999): Regional development agencies and the knowledge economy. Harnessing the potential of universities. Environment and Planning C, 6. 685-699. http://doi.org/cwdbk9

Halkier, H. (2012): Regional development agencies, regional policy and knowledge dynamics. Surveying patterns and trends in Europe. In: Bellini, N., Danson, M., Halkier, H. (eds.): Regional development agencies: the next generation? Routledge, New York, 24-51.

Halkier, H, Danson, M. (1997): Regional development agencies in Western Europe: A survey of key characteristics and trends. European Urban and Regional Studies, 3., 243-256. http://doi.org/dn4pzn

Jones, M. (2001): The rise of the regional state in economic governance: 'Partnership for prosperity' or new scale of power? Environment and Planning A, 7., 1185-1211. http://doi.org/bmkrhq

Józsa V. (2016): A magyarországi regionalizmus egy gyakorlati ember szemével. Tér és Társadalom, 1., 37-55. http://doi.org/crtv 
Miles, N., Tully, J. M. (2007): Regional development agency policy to tackle economic exclusion? The role of social capital in distressed communities. Regional Studies, 6., 855-866. http://doi.org/bj237q

Morgan, K. (1998): Regional renewal. The development agency as animateur. In: Halkier, H., Danson, M., Damborg. C. (eds.): Regional development agencies in Europe. Routledge, London, 229-252. http://doi.org/c7k2

Nemzeti Fejlesztési és Gazdasági Minisztérium (2009): A hazai területfejlesztési és támogatási rendszer átfogó értékelése (1996-2008). Budapest

Visser, E-J., Atzema, O. (2008): With or without clusters: Facilitating innovation through a differentiated and combined network approach. European Planning Studies, 9., 1169-1188. http://doi.org/bb7fdd 